\title{
In der Warteschlaufe
}
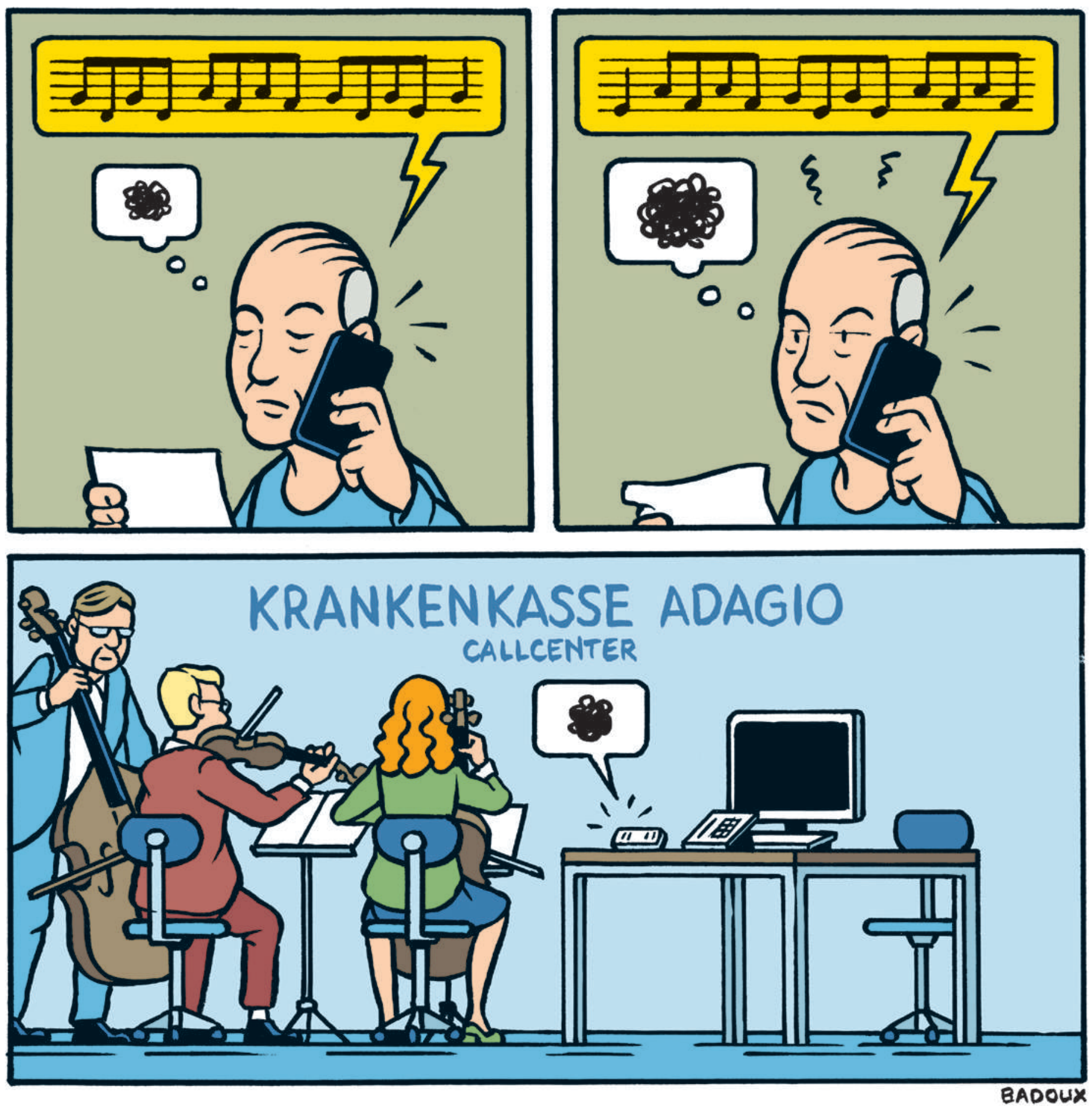